\title{
Ampicillin in the treatment of imprisoned patients with gonorrhoea
}

\author{
T. JERSILD AND T. LYSBO SVENDSEN \\ Vestre Hospital, Copenhagen, Denmark
}

It is generally acknowledged that a reduction in the sensitivity to penicillin of several gonococcal strains is leading to an increase in therapeutic failures. Since 1963 we have tentatively used ampicillin (Doctacillin $\left.{ }^{\circledR}\right)$ to treat gonorrhoea infections in patients in the Copenhagen prisons. The acid stability of ampicillin, the satisfactory absorption of the drug from the gastrointestinal canal, the fact that its free concentration in plasma is higher than that of penicillin $G$ (owing to its reduced binding to plasma proteins), and its intensified bactericidal action on gonococcal strains with reduced sensitivity to penicillin G (Ödegaard, 1962) provide the theoretical basis for the application of the drug.

In the treatment of imprisoned patients the finding of positive cultures after treatment always points to therapeutic failure, whereas among out-patients it may be difficult to decide between treatment failure and re-infection (Willcox, 1964). Accordingly, the present series, in which all the patients were isolated in hospital or in prison awaiting trial, provided ideal data to assess the efficacy of ampicillin therapy.

\section{Methods}

From 1963 to 1966, a series of 182 patients with gonorrhoea received a single dose of $1 \mathrm{~g}$. ampicillin by mouth. Gonorrhoea recurred in fourteen patients ( 7.7 per cent.) (Jersild, 1966). In the period from 1969 to 1970, all patients with gonorrhoea were classified according to their dates of birth, and patients born on odd dates received single doses of $1 \mathrm{~g}$. ampicillin by mouth (Group I) while patients born on even dates received an additional dose of $1 \mathrm{~g}$. of ampicillin 24 hours after the first (Group II). Group I comprised 39 male and 37 female patients and Group II 55 male and 19 female patients. The diagnoses were in all cases established on the basis of bacteriological cultures. In all cases at least one follow-up test was performed; two follow-up tests in 87 per cent. of the cases, three in 70 per cent., and four in 15 per cent. These tests were made at about 3-day intervals, and included smears and cultures. Sensitivity tests to penicillin $G$ and ampicillin, using the

Received for publication August 1, 1972 plate-dilution method, were performed in the Statens Seruminstitut, Copenhagen. The $\mathrm{IC}_{50}$ values for penicillin $G$ and ampicillin are shown in the Figure. The dividing line between sensitive strains and strains with reduced sensitivity is the same for the two preparations.

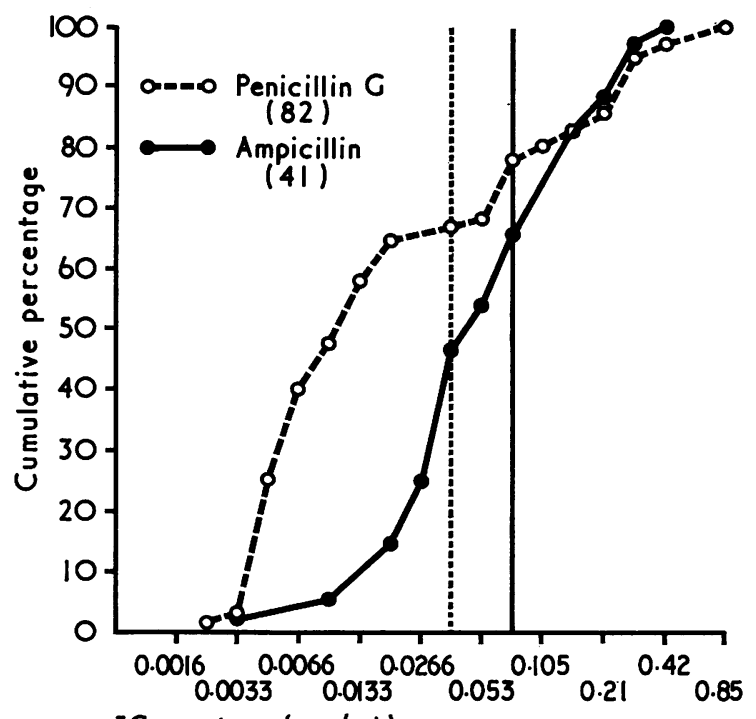

$I C_{50}$ values $(\mu \mathrm{g} / \mathrm{ml})$

FIGURE Cumulative distribution of $I_{50}$ values

\section{Results}

Growth of gonococci was demonstrable at the first follow-up test in seven patients (4.7 per cent.) (Table I); six of these positive cultures were derived from patients in Group I (1 g. ampicillin in one dose) in which the incidence of recurrence was 7.9 per cent., compared with 1.4 per cent. in Group II (1 g. ampicillin given twice). Table I shows that later follow-up cultures were all negative. The incidence of recurrences was highest among the male patients in Group I, being 12.8 per cent. compared with 1.8 per cent. among the male patients in Group II (Table II). 
TABLE I Results obtained with two different doses of ampicillin, by sex

\begin{tabular}{|c|c|c|c|c|c|}
\hline \multicolumn{2}{|l|}{ Group } & \multirow{2}{*}{\multicolumn{2}{|c|}{ One dose of 1}} & \multirow{2}{*}{\multicolumn{2}{|c|}{$\frac{I I}{T w o \text { doses of } 1 \mathrm{~g} .}$}} \\
\hline \multirow{2}{*}{$\begin{array}{l}\text { No. of } \\
\text { follow-up } \\
\text { tests }\end{array}$} & \multirow[b]{2}{*}{ Sex } & & & & \\
\hline & & $\begin{array}{l}\text { Negative } \\
\text { culture }\end{array}$ & $\begin{array}{l}\text { Positive } \\
\text { culture }\end{array}$ & $\begin{array}{l}\text { Negative } \\
\text { culture }\end{array}$ & $\begin{array}{l}\text { Positive } \\
\text { culture }\end{array}$ \\
\hline 1 & $\begin{array}{l}\mathbf{M} \\
\mathrm{F}\end{array}$ & $\begin{array}{l}34 \\
36\end{array}$ & $\begin{array}{l}5 \\
1\end{array}$ & $\begin{array}{l}54 \\
19\end{array}$ & 1 \\
\hline 2 & $\begin{array}{l}\mathrm{M} \\
\mathrm{F}\end{array}$ & $\begin{array}{l}33 \\
29\end{array}$ & & $\begin{array}{l}50 \\
13\end{array}$ & \\
\hline 3 & $\begin{array}{l}\mathbf{M} \\
\mathbf{F}\end{array}$ & $\begin{array}{l}27 \\
25\end{array}$ & & $\begin{array}{r}44 \\
9\end{array}$ & \\
\hline 4 & $\begin{array}{l}\mathbf{M} \\
\mathbf{F}\end{array}$ & $\begin{array}{l}7 \\
4\end{array}$ & & $\begin{array}{r}10 \\
1\end{array}$ & \\
\hline
\end{tabular}

The difference is statistically significant at the 5 per cent. level $(P=0.04)$. Gonococci with reduced sensitivity to penicillin $G$ were found in five out of the six patients in Group I in whom gonorrhoea recurred; in three of the latter cases, treatment with ampicillin was repeated, using the divided dose. The following two to four follow-up cultures from these patients were negative. Only one complication was encountered in the whole series-an intense allergic reaction manifested by a generalized rash and respiratory difficulty. The patient recovered rapidly after adequate treatment.

TABLE II Incidence of positive cultures at first follow-up test, by sex

\begin{tabular}{|c|c|c|c|c|}
\hline \multirow{2}{*}{ Sex } & \multicolumn{2}{|c|}{$1 \mathrm{~g}$. in one dose } & \multicolumn{2}{|c|}{$2 \mathrm{~g}$. in two doses } \\
\hline & No. & Per cent. & No. & Per cent. \\
\hline $\begin{array}{l}\mathbf{M} \\
\mathbf{F}\end{array}$ & $\begin{array}{l}39 \\
37\end{array}$ & $\begin{array}{r}12 \cdot 8 \\
2 \cdot 7\end{array}$ & $\begin{array}{l}55 \\
19\end{array}$ & $\begin{array}{l}1.8 \\
0.0\end{array}$ \\
\hline Total & 76 & $7 \cdot 9$ & $\mathbf{7 4}$ & 1.4 \\
\hline
\end{tabular}

\section{Discussion}

Cure was obtained in 87.2 per cent. of the male patients after oral administration of $1 \mathrm{~g}$. ampicillin. This is similar to the percentage reported by Willcox (1963) and by Bro-Jørgensen and Jensen (1971). Alergant (1963), who used the same dosage, obtained a cure-rate of 95 per cent.

The results obtained in the present investigation with $1 \mathrm{~g}$. ampicillin are unsatisfactory and much inferior to those obtained by $1 \mathrm{~g}$. probenecid by mouth and 5 million i.u. penicillin $G$ by intramuscular injection, with which Olsen and Lomholt (1969) obtained a cure rate of 99 per cent.
Cure was obtained in 98 per cent. of our cases by oral administration of two doses of $1 \mathrm{~g}$. ampicillin. Eriksson (1970a) and Groth and Hallqvist (1970) obtained the same cure-rate in their patients who received the same dosage administered with a 5-hour interval.

Owing to the small size of the series, it was not possible to demonstrate a statistically significant difference in the results among women in the two groups, but the overall results are in agreement with those reported by Eriksson (1970b).

It is concluded that the results obtained from single oral doses of $1 \mathrm{~g}$. ampicillin are unsatisfactory. On the other hand, the results obtained from two doses of $1 \mathrm{~g}$. ampicillin are comparable with those obtained from penicillin $G$ and probenecid. In the treatment of out-patients, however, such divided doses may involve the risk that some patients will fail to take the second dose, and the therapy is therefore recommended for the treatment of those in hospital or in prison.

Gundersen, Ödegaard, and Gjessing (1969) and Bro-Jørgensen and Jensen (1971) obtained recovery in 99 per cent. of their patients who received $2 \mathrm{~g}$. ampicillin and $1 \mathrm{~g}$. probenecid. Thus this must be considered an excellent alternative to conventional therapy and well suited for the treatment of outpatients. It may be argued against treatments using penicillin and probenecid that the incidence of allergic reactions is higher after penicillin plus probenecid than after penicillin alone (Eriksson, $1970 \mathrm{~b}$ ), especially when treatment is prolonged. Also, penicillin, the allergen involved in such allergic reactions, is excreted less rapidly from the organism. These objections are not of major importance at the moment, but the increasing incidence of allergic reactions to penicillin in the population may make it necessary to take them into consideration in the future.

\section{Summary}

From 1963 to 1966, a series of 182 patients in Vestre Hospital and in the Copenhagen prisons were treated for gonorrhoea with single doses of $1 \mathrm{~g}$. ampicillin by mouth. The incidence of recurrences among them was $7 \cdot 7$ per cent. From 1969 to 1970 , patients with gonorrhoea were classified according to their dates of birth; those born on odd dates (Group I) received $1 \mathrm{~g}$. ampicillin by mouth and those born on even dates (Group II) received a second dose of $1 \mathrm{~g}$. ampicillin $24 \mathrm{hrs}$ after the first. The recurrence rate was 7.9 per cent. in Group I (39 males and 37 females); for male patients only it was 12.8 per cent. In Group II ( 55 males and 19 females) the recurrence rate was 1.4 per cent. ; for male patients only it was 1.8 
per cent. The difference in the results for males in the two groups is statistically significant. Failure was observed in only one of the women who received the two doses. Only one allergic reaction was encountered in the entire series of patients treated with ampicillin (a total of 332).

On the basis of these findings it seems reasonable to recommend ampicillin in two doses of $1 \mathrm{~g}$. in the treatment of patients with gonorrhoea who are in hospital or in prison.

The authors wish to acknowledge their indebtedness to Astra Ltd., Stockholm, who did the statistical analyses and supplied the ampicillin (Doctacillin ${ }^{(B)}$ ).

\section{References}

Alergant, C. D. (1963) Brit. F. vener. Dis., 39, 225

BRo-JøRGENSEN, A., and JENSEN, T. (1971) Ugeskr. Laeg., 133, 1253

ErIKsson, G. (1970a) Acta derm.-venereol. (Stockh.), 50, 451

- (1970b) Ibid., 50, 461

Groth, O., and HALlQvist, L. (1970) Brit. F. vener. Dis., 46, 21

Gundersen, T., Ödegaard, K., and Gjessing, H. C. (1969) Ibid., 45, 235

JERSILD, T. (1966) 'Peroral behandling med ampicillin af gonoré i Kobenhavns fænglser.' Foredrag afholdt for fængselslæger og embedslæger den 4.12.1966

ÖDEGAARD, K. (1962) T. norsk Laegeforen., 82, 55
Olsen, G. A., and Lomholt, G. (1969) Brit. f. vener. Dis. 45, 144

WILLCox, R. R. (1963) Ibid., 39, 164

- (1964) Ibid., 40, 261

L'ampicilline dans le traitement des gonococciques incarcérés

SOMMAIRE

De 1963 à 1966, une série de 182 malades de l'Hôpital Vestre et des prisons de Copenhague furent traités pour gonococcie par des doses uniques buccales de $1 \mathrm{~g}$. d' ampicilline. L'incidence des rechutes parmi eux fut de 7,7 pour cent. De 1969 à 1970, les gonococciques furent répartis selon la date de leur naissance; les sujets nés une année impaire (groupe I) reçurent $1 \mathrm{~g}$. d'ampicilline buccale et ceux nés une année paire (groupe II) reçurent une dose d'1 g. 24 heures aprés la première. Le taux de rechute fut de 7,9 pour cent dans le groupe I (39 hommes et 37 femmes); pour les hommes considérés séparément, 1 ' incidence fut de 12,8 pour cent. Dans le groupe II (55 hommes et 19 femmes), le taux de rechute fut de 1,4 pour cent; pour les hommes seuls, il fut de 1,8 pour cent. La différence des résultats masculins pour les deux groupes est statistiquement significative. Un seul échec fut observé chez les femmes ayant reçu une seule dose et aucun chez celles ayant reçu deux doses. Pour l'ensemble des malades, une seule réaction allergique fut mentionnée après l'ampicilline (sur un total de 332 malades).

Au nom de ces résultats, il semble raisonnable de recommander l'ampicilline à la posologie de 2 doses de 1 g. pour le traitement des gonococcies à l'hôpital ou en prison. 